\title{
NEW PLANT BREEDING TECHNOLOGIES FOR A SUSTAINABLE AGRICULTURE
}

\author{
MARTIN KATER $(*)$ \\ Nota presentata dal m.e. C. Soave \\ (Adunanza del 9 marzo 2017)
}

\begin{abstract}
SuNTO. - L'Agricoltura ha una storia lunga 10.000 anni. Durante questo periodo l'uomo ha selezionato mutanti naturali che risultavano essere utili per la coltivazione e il consumo umano. Tuttavia le caratteristiche selezionate non sono sempre favorevoli per le piante stesse, compromettendo spesso la loro capacità di sopravvivenza e adattamento nell'ambiente naturale. In questo modo le piante coltivate sono diventate dipendenti, per loro sopravvivenza, dall'uomo come l'uomo è dipendente dalle piante per sopravvivere. L'incremento della produzione agricola è stata notevole durante la rivoluzione verde e anche successivamente le nuove conoscenze genetiche hanno permesso di aumentare drasticamente la produzione di cibo. Tuttavia adesso con la rapida crescita della popolazione mondiale si è reso necessaria la selezione di nuove piante coltivate non solo in grado di produrre di più ma anche lo riescano a fare con meno risorse di acqua, fertilizzanti, insetticidi etc. Piante che siano più resistente a stress biotici e abiotici, sempre più frequenti in un mondo dove i cambiamenti climatici stanno diventando una grossa sfida per il futuro. Studiare i genomi delle piante e la funzioni dei loro geni è l'unico modo per poter accelerare il miglioramento genetico delle piante tutelando contemporaneamente l'ambiente. Una tecnologia molto importante per cercare di risolvere queste problematiche è il "genome editing", usando il sistema CRISPR-Cas. Purtroppo, in Europa l'uso di questa nuova tecnologia in agricoltura ha trovato non è di facile applicazione non tanto per motivazioni scientifiche ma per ideologie politiche contrarie a questo tipo di innovazione in agricoltura.
\end{abstract}

$$
* * *
$$

(") Department of Biosciences, Università degli Studi di Milano, Italy.

E-mail: martin.kater@unimi.it 
ABSTRACT. - Agriculture has a 10,000-year history. During this period, humans selected natural mutants that were found to be useful for cultivation and human consumption. However, the selected characteristics are not always favorable for the plants themselves, often compromising their ability to survive and adapt to the natural environment. In this way, cultivated plants have become dependent, for their survival, on man as man is dependent on plants to survive. The increase in agricultural production was notable during the green revolution and even afterwards new genetic knowledge made it possible to drastically increase food production. However, now with the rapid growth of the world population, the selection of new cultivars has become necessary, not only capable of producing more but also able to do so with less water, fertilizers, insecticides etc. Plants that are more resistant to biotic and abiotic stresses, which are increasingly frequent in a world where climate change is becoming a major challenge for the future. Studying the genomes of plants and the functions of their genes is the only way to accelerate the genetic improvement of plants while protecting the environment. A very important technology to try to solve these problems is "genome editing", using the CRISPR-Cas system. Unfortunately, in Europe the use of this new technology in agriculture has found it is not easy to apply not so much for scientific reasons but for political ideologies contrary to this type of innovation in agriculture.

Agriculture has a long history. About 10.000 years ago agriculture started in different parts of the world (Fig. 1). Important in this respect is the domestication of plants, which means that humans were selection natural mutants that showed favourable traits. The rare mutants or hybrids that they found in nature were not all used for consumption but they preserved them for the next season. In this way wild plant species were slowly on transformed into domesticated plants.

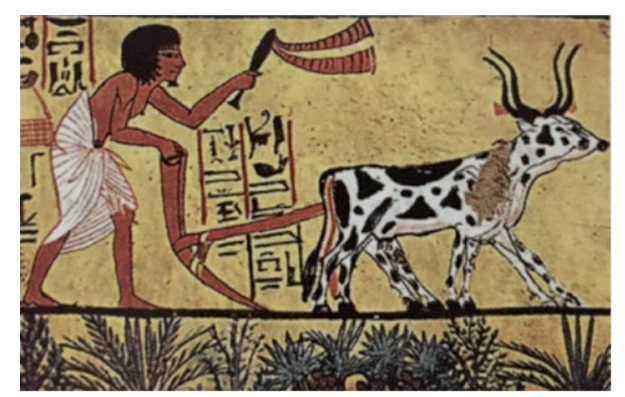

Fig. 1.

One of the most important characters that was independently selected in several grass species (cereals like wheat and rice) was the loss of seed shattering (Fig. 2). This allowed easy harvesting, instead of picking up seeds from the soil the seeds remained fixed to the plant. This 
boosted food production. It is believed that this is one of the mutations that allowed human settlements instead of being nomads. The plants that can't spread their seeds anymore became dependent on humans and we became dependent on our domesticated plants for our food supply.

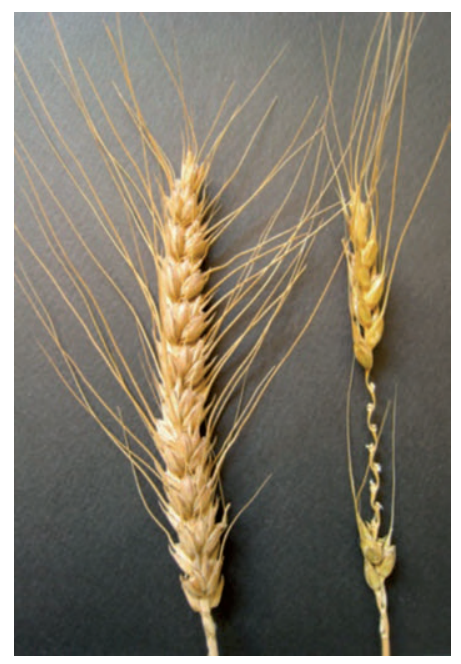

Fig. 2.

During the last 60 years, the green revolution (1950-1960) and subsequent integration of advanced research based innovation has drastically boosted agricultural output and has resulted in food abundance, particularly in the developing world. However, with the increasing world population, expected to reach 10 billion people in 2050 , food production is becoming under pressure and yearly yield increases per hectare are likely to fall short the demand. Therefore, a new Green Revolution is needed to boost production per hectare but it has to be a sustainable "revolution" (Fig. 3). We will need crops with high yield potential, that need less water, less fertilisers, that are tolerant to biotic and abiotic stresses. Production per hectare needs to increase also because we can't keep on increasing agricultural land on the costs of natural habitats, like the tropical forests. We will have to produce "MORE" with "LESS". Is this possible?

Many technologies are being developed. Not only to improve our crops but also how we cultivate them. Satellite guided irrigation systems are a good example of high-tech agricultural practises. 


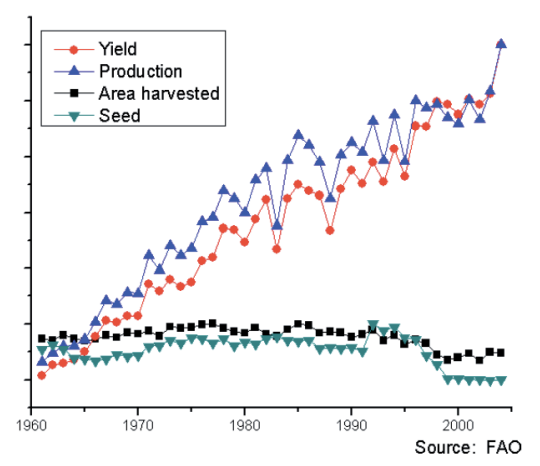

Fig. 3.

Plant Biotechnology for crop improvement is now approaching these challenges from a genomics perspective. Whole plant genomes are massively being sequenced through the application of high-tech DNA sequencing approaches, which are still rapidly increasing their capacity at a continuously reducing costs.

What can we do with the information that we get from these genomes. Many things, like comparing plant genomes, but important is that we can annotate the "complete" set of genes that a plant genome encodes. Considering that we have experimentally studied the function of about $5 \%$ of the genes of rice, you can imagine that obtaining functional knowledge about the remaining $95 \%$ of genes is an enormous resource for further crop improvement.

Summarising this part, in the past 10.000 years we have selected favourable mutations based on the plant phenotypes. Now in the new biotech era we select first the genes and create favourable mutations.

Genetically modified organisms (GMOs), by introducing beneficial genes from wild relatives or unrelated species is a technology that hasn't been accepted, especially in Europe, by a wide public and politicians. However, we already modify for years our plants by mutagenising them and subsequently selecting favourable mutations. Despite that this has a drastic impact on the genome, this technology has been broadly accepted and our daily food is largely coming from plants that have been mutagenised in this way.

Recently, a bacterial immune based system named CRISPR-Cas9 has substantially improved our tool kit to modify genomes (Fig. 4).

This system allows making mutations in specific locations in the 
genome. We still have to introduce a transgene into the genome of a plant that contains the CRISPR-Cas based mutagenesis system. It makes mutations in a desired place of the genome and after that event we don't need the transgene any longer and it can simply being removed by crossing. This means that the transgene itself doesn't provide the favourable trait but it just creates the favourable mutations somewhere in the genome.

Introducing a specific mutation by CRISPR-Cas technology

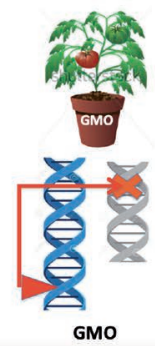

CRISPR plant

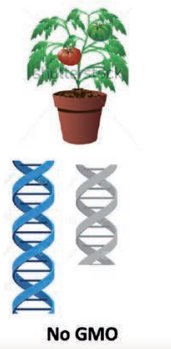

Wild type
Mendelian Genetics

Offspring
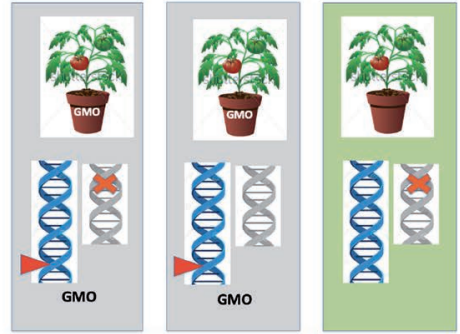

GMO or

not?

Transgene

\section{Mutation}

Fig. 4.

The question now is: such a mutagenised plant that doesn't contain a transgene is it a GMO? Scientifically speaking it isn't but the European parliament is not so sure... 
